京都府立医科大学, 解剖学教室 (野田秀俊教授).

Anat. Inst. d. Med. Akad, d. Kyoto-Präfektur (Vorstand : Prof. H. NODA).

\title{
神経分泌物の腺性下垂体への進入について.
}

(視床下部下垂体系の比較組織学的研究. 第 7 報.)

\section{Über den Eintritt des Neurosekrets in die Adenohypophyse.}

(Beiträge zur vegleichenden Histologie des Hypothalamus-

Hypophysensystems. 7. Mitteilung.)

野田秀俊, 佐野 豊, 中村清

Hidetoshi NODA, Yutaka SANO, Kiyoshi NAKAMURA.

(昭和 30 年 3 月 17 日原稿受付.)

視床下部の神経分泌核で作られた分泌物は, 神経分泌路によって後葉其 の他飞運ばれるが，その一部が後葉から更に中間葉の腺細胞間隙, 或は㴔 胞の周辺飞浸潤することが報告されている. 即ち Bargmann（1949）, Bargmann, Hild, Ortmann, Schiebler (1950) は犬, Dawson (1953) は 蛙 (Rana pipiens), Scharrer.(1952) はサメ類 (Scyllium), 更飞 Bargmann （1953） は軟鯺頑（Gadus タラ）飞扔いて夫々報告している。私達は種々 の哺乳類，及び蛙飞招いて得られた神経分泌物の腺性下垂体への進入所見 をとりまとめて報告する。

\section{I. 材料 と方法.}

哺乳類（犬, 猫, 豹, 豚, 家鬼) 及びトノサマガエルの視床下部下垂体 系を一体として剔出し, Zenker 固定の Paraffin 切片に, 主として Gomori 染色をほどこして検索した。

\section{II. 所見と考察.}

1. 隆起部 (Pars tuberalis oder infundibularis adenohypophyseos) への 進入.

一般飞神経性下垂体と腺性下垂体の間飞は，脳膜に由来する格子線維性 の境界膜があって両者をへだてているが，漏斗近位部 (median eminence) そ招いてはとの内層を形成する gomoriphil の神経分泌路は，更飞上衣細 胞線維と nicht gomoriphil の神経線維よりなる外層 (periphere Zone von Nowakowski）飞よって隆起部とへだてられているためと，神経分泌物が 内層 (zentrale Zone von Nowakowski) から隆起部腺組織の細胞間隙に進 大している所見には極めて稀にしか遭遇しない. しかし犬及び猫の少数 


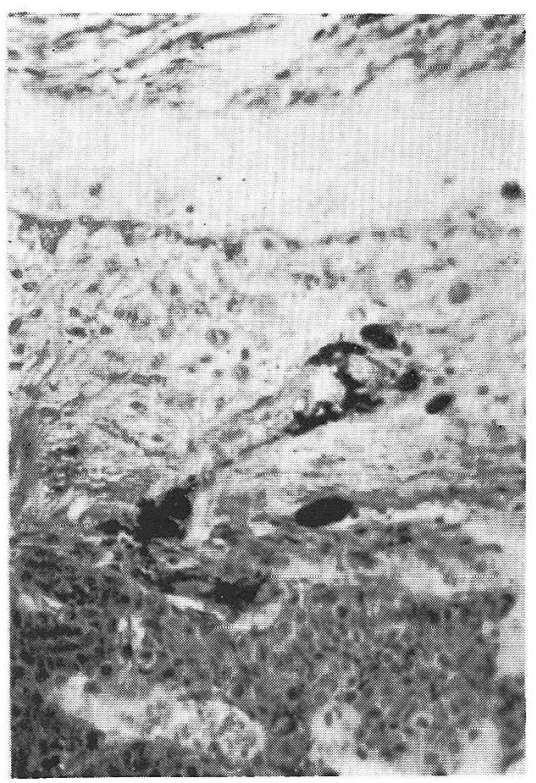

兴 1. 洞血管（犬）の壁に沿い隆起部に進 入せる Gomori 好性物質: Zenker, Paraffin, $8 \mu$, Gomoris CHP 染色. 340 俈.

Abb 1. Gomoriphiles Neurosekret, das der Sinuskapillarwand entlang in die Pars tuberalis eindringt. (Hund). ZENKER, Paraffin, $8 \mu$, GOMORIs CHP-Färbung. $340 \times$
例，豹及び豚の各1例に括いて， gomoriphil の物質が，下开俶川水

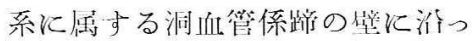

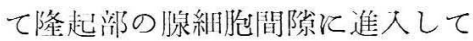
いる所見が認められた。

2. 反伝带 (Umschlagszone von Lothringer）への進入.

この部は広義に招ける中間葉 と属し，神経惟下垂体の介在部 (Zwischenstück, 人の漏斗迹隹部 即ち漏斗唡飞該当する）と接して いるが，介在部には外層がないた め gomoriphil の神経分泌路と反 転带との間には境界脱が存するの みである.犬及び猫ではこの境界 膜をこえて多数の gomoriphil の 顆粒が腺細胞間吵飞進入している 所見が廔々認められる。この埸合 そは必ずしも洞血管係踇と関係な く, 又 perlschnurartig な線維と してでもなく, gomoriphil の物質 は殆んぞ常に顆䊉状の一時には

所謂 Herring 小休の一形で認められる.

3.中間葉への進入。

犬，猫，家鬼及びトノサマガエルのいずれそ於ても，gomoriphil の物質 が後葉周辺部から境界膜るこえて中間葉内飞進入している所見が㴓められ る。之等の動物では，Scharrer（1952）や Bargmann（1953）が魚類で報

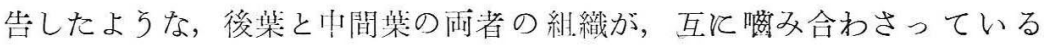
(Verzahnung) 所見はなく，また网者の閻には Bielschowsky-Maresch 鍍銀 法で明確に，主として格子線維性の境界膜を示すことが出米る。即ちと等 の動物ではこの膜をこえて神経分泌物が中間笨内《進大するのである。し か子その進入部位は一定でなく，反転带に怙けると同様に顆粒状の分泌物 として認められることが多い，特炕犬では滤胞をとりまいて進入するもの と，滤胞之無関係飞進入するものとの別がある，何れも群をなして同一ケ 所から進入している. 


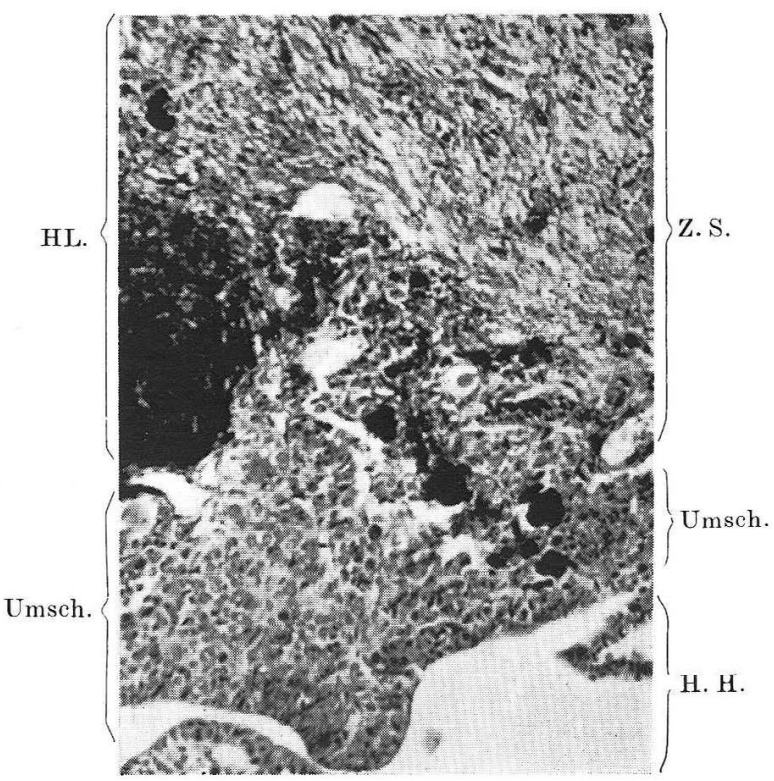

欲2. 反転带(犬)腺 紐胞間飞進入せる Gomori 好性物澌. Zenker, Paraffin, $8 \mu$, Gomor is CHP 染色. 200 倍.

$\mathrm{Abb} 2$. Gomoriphiles Neurosekret, das zwischen den Drüsenzellen der Umsch1agszone eindringt. (Hund). ZENKER, Paraffin, $8 \mu$, GOMORIs CHPFärbung. $200 \times$

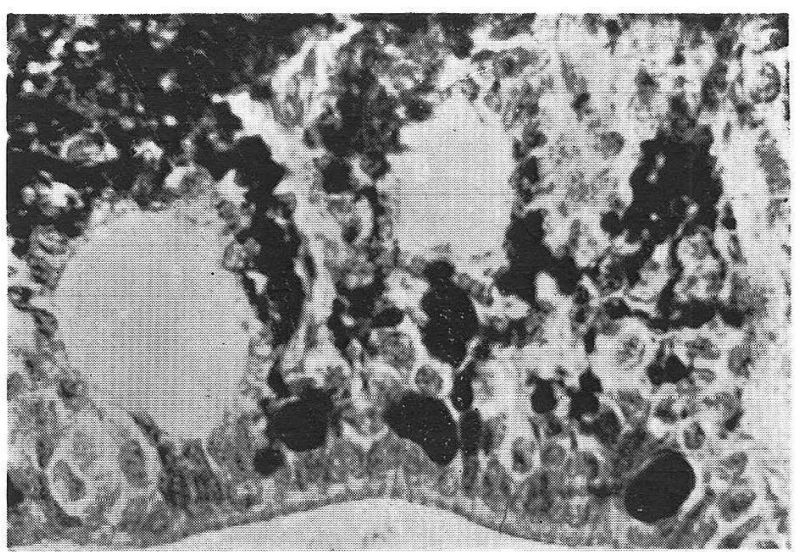

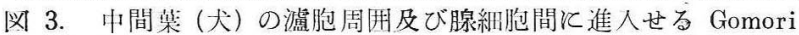
好性:物質 : Zenker ; Paraffin, $8 \mu$; Gomoris CHP 染色. 490 倍.

Abb 3. Gomoriphiles Neurosekret, das in die Umgebung des Follikels des Zwischenlappens und zwischen deren Drüsenzellen eindringt. (Hund). ZENKER, Paraffin, $8 \mu$, GOMORIs CHP-Färbung. $430 \times$ 
之等の動物の中間葉に捈ける神経線維の存在とついては, 既に Gemelli (1906), Dandy（1913）及び Pines（1926）は犬で, Dandy（1913）及び Hair（1938）は猫で, Croll（1928）及び長谷川（1954）は家鬼で，それぞ れその存在を認め, しかもとの線維は神経性下垂体一主として後葉一に 由来するものと考光ている。私達が中間葉で認めた gomoriphil の物質は, 漏斗近位部内層飞於て見られるような線状，或は perlschnurartig な形態 を示さないことが多く一般に顆粒状である. 又との中間葉内に括ける配列 を見ても，恰かも後葉周辺部に渚溜した分泌物が境界膜結合組織網工の間 から中間葉内へ浸潤したかの如く思われる。しかし長谷川（1954）は中間 葉の神経線維がその走行中に小腫瘤や原線維網の離開を示すと述べて括 り，或はか」る場所に一致して gomoriphil の物質が渚溜しているのかも 知れない，何れにしても腺性下垂体に認められる gomoriphil の物質と神 経線維との関係は未だ明らかではない。

III. 結 語.

神経分泌物の Neurohypophyse から Adenohypophyse への進入を検索 して次の所見を得た。

1. 犬，猫，豹及び豚と抒いて gomoriphil の神経分泌物が洞血管係蹄 の壁飞沿つて漏斗近位部内層から隆起部内に進入している所見を認めた。

2. 犬及び猫に於て gomoriphil の顆粒——時には Herring 小体一が, 介在部（Zwischenstück）より反転带（Umschlagszone）の腺細胞間隙飞進 大している所見を認めた。

3. 犬，猫，家鬼及びトノサマガエルに於て多数の gomoriphil の顆粒 が集団をなして後葉から中間葉腺細胞間及び滤胞周辺部に進入する所見を 認めた。

\section{Autoreferat.}

Wir untersuchten den Eintritt des gomoriphilen Neurosekrets in die Adenohypophyse bei Säugetieren und beim Frosch.

1. Bei einigen Katzen, Hunden, einem Schwein und einem Leopard wurden gomoriphile Neurosekrete, die von der inneren Zone des proximalen Abschnittes (median eminence) des Trichters den sinuösen Gefäßschleifen entlang in den Trichterlappen (Pars tuberalis adenohypophyseos) eingetreten waren, beobachtet.

2. Bei Hunde und Katze wurden gomoriphile Sekretgranula - bisweilen die HERRINGschen Körper - , die von dem Zwischenstück (dem Trichterstiel des Menschen entsprechender Abschnitt) in die Interzellular- 
lücken der Ümschlagszone eingetreten waren, beobachtet.

3. In allen Fällen von Hund, Kaninchen und Rana nigromaculata wurden gomoriphile Sekretgranula, die von den Hinterlappen gruppenweise in die Interzellularlücken und Follikelumgebung des Zwischenlappens eingetreten waren, beobachtet.

\section{文献.}

Bargmann, W. : Z. Zellforsch. 34 (1949). S. 610. - Z. Zellforsch. 38 (1953). S. 275. - Bargmann, W., W. Hild, R. Ortmann u. T.H. Schi eber : Acta neuroveg. 1 (1950). S. 233. - Croll, M. : J. Physiol. 66 (1928). P. 316. - Dandy, W. E. : Amer. J. Anat. 15 (1913-14). P. 333. - Dawson, A. B. : Anat. Rec. 115 (1953). P. 63. - Gemelli, A. : Anat. Anz. 28 (1906). S. 613. 一 Hair, G. W. : Anat. Rec. 71 (1938). P. 141. 一長谷川英一：解剖誌. 29 (1954). 頁 222. - Nowakowski, H. : Dtsch. Z. Nervenhk. 165 (1951). S. 261. - Pines, I. L. : J. Psychol. u. Neur. 32 (1925). S. 80. - Z. Neur. 100 (1925). S. 123. - Z. Neur. 107 (1927). S. 178. - Scharrer, E. : Z. Zellforsch. 37 (1952). S. 195. 